\title{
Creating and contesting hierarchy: the punitive effect of sanctions in a horizontal system
}

\section{Creación y contestación de la jerarquía: efecto punitivo de las sanciones en un sistema horizontal}

\section{Alexandra Hofer}

Assistant professor in Public International Law, Department of International and European Law, Utrecht University. a.s.hofer@uu.nl

How to cite this article: Hofer, Alexandra. "Creating and contesting hierarchy: the punitive effect of sanctions in a horizontal system". Revista CIDOB d'Afers Internacionals, issue 125 (September 2020), pp. 15-37. DOI: doi.org/10.24241/rcai.2020.125.2.15/en

\begin{abstract}
Sanctions are presented as a form of international punishment that not only stigmatises the target, but creates a hierarchy between those who impose punishment and those punished. Such practices go against the principle of sovereign equality and contradict the horizontal structure of the international system. Drawing on the literature on stigma management and resentment, this paper argues that when states react to sanctions, they respond not only to the imposition of stigma, but also to the inferior position in which they are placed. Targets may resent the position of authority adopted by the sanctioners. This may in turn motivate them to contest the status quo upon which sanctioners justify their authority, thereby reasserting the norms and corresponding practices they believe should be prioritized.
\end{abstract}

Key words: international hierarchy, unilateral sanctions, international punishment, stigma management, resentment, international relations
Resumen: Las sanciones se describen como una forma de castigo internacional que no solo estigmatiza a los destinatarios, sino que también crea una jerarquía entre los que imponen el castigo y los que son castigados. Dichas prácticas van en contra del principio de igualdad soberana y contradicen la estructura horizontal del sistema internacional. A partir de la literatura sobre la gestión del estigma y el resentimiento, la presente contribución sostiene que cuando los estados reaccionan a las sanciones, responden no solo a la imposición del estigma, sino también a la posición inferior en la que son situados. Los destinatarios pueden estar resentidos por la posición de autoridad adoptada por los emisores. Ello, a su vez, puede motivarles a poner en tela de juicio el statu quo por el cual los sancionadores justifican su autoridad $y$, de ese modo, reafirman las normas y las prácticas correspondientes que consideran que deberían priorizarse.

Palabras clave: jerarquía internacional, sanciones unilaterales, castigo internacional, gestión del estigma, resentimiento, relaciones internacionales 
The international legal order is frequently characterized as a horizontal, or anarchic, system where no central authority exists. Within this decentralized system, sanctions are viewed as a means of self-help available to states or international organizations seeking redress. Additionally, they are adopted in order to enforce community norms that are of interest to the international community as a whole as each state is concerned with their compliance. The European Union (EU) and the United States of America (US) have become active sanctioners in this regard; they frequently adopt coercive measures in response to human rights violations, particularly in response to breaches of civil and political rights such as those committed by President Maduro's regime in Venezuela (OHCHR Report, 2017), and in reaction to situations that threaten international peace and security, for example measures have been taken in support of efforts to counter weapons' proliferation and terrorist activities. The EU and US also took the lead in sanctioning Russia in 2014 for violating Ukraine's territorial and sovereignty integrity, a breach of the prohibition to use force. Other states, notably Canada, Australia or non-EU European countries, sometimes align with these sanction regimes. In spite of the fact that the meaning of the 'international order' remains unclear, sanctioning practices by third parties help clarify which norms lie at the basis of the international order (Adler-Nissen, 2014) and contribute to their robustness (Deitelhoff and Zimmermann, 2019: 3; see also Erickson, 2020). On the other hand, an important number of states - not only the targets of sanctions but also third countries - frequently contest the adoption of unilateral coercive measures (Hofer, 2017a and 2017b). They do so by invoking the norms that senders violate when imposing such measures.

Adopting a symbolic interactionist approach (McCourt, 2012; Smetana, 2019; Hofer, 2020), the present article seeks to understand what motivates this contestation, thereby providing further insight on how unilateral sanctions influence inter-state relations. It is suggested that sanctions' punitive nature, implying a hierarchy between the sender and the target, is what triggers contestation against these practices. States may experience resentment against being placed in a lower status and thereby attempt to correct it by invoking the norms they believe should organise inter-state interactions. In other words, contestation is a practice that enables states to manage international punishment.

The following section introduces the contestation against sanctions and the approach adopted in this article. Sanctions are then defined as a form of international punishment that enable the senders to adopt the role of authorities in the international order. Drawing from the literature on stigma management and resentment, the third section demonstrates how contestation is a practice that enables states to manage punishment. The final section concludes. 


\section{Contesting unilateral sanctions}

Within the horizontal system sovereign equality is considered a cardinal, albeit ambiguous, principle. It encompasses the notion that no state has sovereignty over another state, or that "no state is legally superior to another" (Simpson, 2003: 28), but this is put in practice in varying degrees. Simpson has unpacked sovereign equality and found it contains legislative, formal and existential equality. It is the latter that is most relevant to the present discussion on unilateral sanctions. Existential equality is the foundation for a pluralist conception of the international legal order; it guarantees states' freedom to choose and develop their political, social and economic systems (ibid: 5354). It is defined as: "a right to exist (territorial integrity), the right to choose the manner of existence (political independence) and the right to participate in the international system as a consequence of the first two rights: so, that the corollary of existential equality is the norm of non-intervention and the right to choose one's own form of government free from external interference" (ibid: 54). In Simpson's view, "legal structures that designate and treat states as outlaws or criminals or failed states deprive this small proportion of states of their sovereign rights" and contradict existential equality (ibid.: 55).

Despite their theoretical equality, in practice states are de facto unequal and are organized within a hierarchical structure (Bially Mattern and Zarakol, 2016). The 'superordinate' states are those that have been described as 'normative powers' (Manners, 2003; Diez, 2005), Great Powers (Simpson, 2003), or as the 'audience of normals' (Adler-Nissen, 2014). This group of states play the role of the authority that enforces international norms and through sanctioning practices label states that do not comply with normative expectations as deviants, malign, bad, etc. Though the horizontal structure seemingly depends on autonomous enforcement measures, as a practice that designates and treats states as outlaws or criminals, sanctions deny a proportion of states of existential equality and create a hierarchy between the sanctioner and the sanctioned. This article submits that the hierarchy implied by sanctions, which undermines sovereign equality, explains why a substantial number of members of the international community frequently claim that unilateral sanctions are unlawful and illegitimate.

It is unsurprising that targeted states object to the adoption of sanctions. However to the extent these objections are expressed in normative terms they do have an effect on the construction of the international order. Furthermore, sanctioned states are not alone in making these claims as they enjoy support from a broad segment of the international community. Contestation against unilateral coercive measures is expressed through the 
Group of 77 plus China (hereafter G77) and the Non-Aligned Movement (hereafter NAM), which frequently voice their objection to non-UN sanctions within the United Nations. The opposition between those that impose the measures and those that contest them has been described as a divide between developed and developing states (Hofer, 2017a). It has been explained as originating from how each group of states defines itself and its role in the international community, and the norms it believes should be given precedence. On the one hand, sanctioners perceive themselves as actors that have the power and responsibility to uphold international norms. Unilateral sanctions are a legitimate policy tool to achieve these objectives and thus support the international order. On the other hand, G77 and NAM are essentially composed of states that had, in the vast majority of cases, been colonized and that are now wary of practices that suggest hegemony. These states have a marked preference for multilateral practices - such as the UN Charter and the peaceful settlement of disputes -, which would be undermined by unilateral coercive measures. Developing countries' preference for multilateral practices seems to be confirmed by the fact that they conditionally accept the adoption of UN Security Council sanctions and measures imposed by regional organizations against their own member states, such as the African Union, the Organization of American States or Mercosur (Hofer, 2017b). In accepting the organizations' constitutive acts, member states presumably consent to being subjected to multilateral sanctions. This is not the case of unilateral sanctions, which are adopted by a state on the basis of its own national legislation or by an organization against a non-member state, such as the EU's restrictive measures. In general, it would appear that these states do not dispute the validity of the norm the sanctioners wish to enforce although they do object to sanctioners enforcement of political and civil rights as opposed to cultural and social rights, which would be transgressed by unilateral sanctions -, but object to the legality and legitimacy of autonomous sanctions as an enforcement tool (ibid.).

The norms the G77 and NAM value derive from sovereign equality - in the sense that they guarantee states' existential independence - and combine what Weiner has described as "fundamental norms" and "organising principles" (Weiner, 2014: 36). The former keeps the community together, whereas the latter structure state behaviour (ibid., 2007). The legality of autonomous sanctions themselves, however, would fall within the category of organising principles (ibid., 2014: chap. 6). Though sanctioners adopt sanctions to enforce one category of fundamental norms, notably human rights and democratic principles, according to the targets sanctions fall foil of an- 
other category of fundamental norms. Indeed, for a significant number of states, the principle of sovereign equality and the corresponding prohibition of intervention would play a key role in determining when sanctions can be adopted. The importance of the principle of non-intervention is reflected in the sanctioning practice of regional organizations such as the League of Arab Nations, the African Union and the Association of Southeast Asian Nations (Hellquist, 2014 and 2015). Each region has a divergent reading of the principle of non-intervention that is the product of their historical trajectory and that is subject to re-interpretation. These different interpretations determine when regional organizations can adopt sanctions against member states. In essence, what would be at stake in the developed/developing divide is not so much the community norms that the senders would seek to enforce as these measures' compatibility with other fundamental values. The norms that regulate how norms should be enforced are also qualified as metanorms, which are "norms that create expectations What would be at stake in the developed/developing divide is not so much the community norms that the senders would seek to enforce as these measures' compatibility with other fundamental values. and obligations of norm enforcement and regulate how actors legitimately punish norm violations" (Erickson, 2020: 99).

In order to further understand this divide over the legality and legitimacy of unilateral sanctions, a symbolic interactionist approach is adopted. Practices that involve the adoption and contestation of sanctions are situated within states' quest for status. It is argued that these practices are tools that states pursue in their effort to affirm their desired social rank. So as to better encapsulate the purpose of sanctions in the hierarchy creating process, these measures are described as a form of international punishment. Punishment is the act of imposing a cost on an actor that is responsible for wrongful behaviour. It is vertical by nature, as it is carried out by an authority. When states impose punishment, they adopt a role of authority and place the target into a lesser, subordinate position. Drawing from the literature on stigma management and resentment, it is suggested that contestation against sanctions is fuelled by the desire to correct a status that is perceived as undeserved. Part of what motivates the punished state's contestation against sanctions is explained by its reaction against the role of authority adopted by the sender and the correspondingly subordinate role it is placed in. In an attempt to correct this unfair status, resentful targets engage in strategies of stigma rejection and/ or counter-stigmatization. 


\section{Defending norms through international punishment}

Over the course of the past decades, there has been an increase in autonomous sanctions adopted by indirectly injured states that seek to respond to violations of norms that they believe are fundamental to the international community as a whole. The most active senders in this regard are the US and the EU. These actors adopt sanctions in collaboration with their 'likeminded partners', such as Canada, Australia and European states that align with the EU's restrictive measures. They are willing to respond to situations where 'grave' human rights violations occur, in particular breaches of political and civil rights. They have also worked together in response to threats to peace and international security, notably as a means to strengthen Security Council sanctions regimes concerned with non-proliferation.

There appears to be a social expectation amongst these like-minded countries to adopt autonomous sanctions in response to situations of international crises. A very clear example of this is provided by New Zealand. In 2012, the Ministry of Foreign Affairs and Trade published "The Regulatory Impact Statement". The document recognised that, due to the country's small size and geographic isolation, unilateral sanctions imposed by New Zealand would have limited success in imposing significant costs on the target. Nevertheless, the statement found: "it is important for New Zealand to be able to demonstrate its commitment to addressing situations of concern, by enhancing [its] ability to act in concert with security partners" (The Treasury New Zealand, 2017: 4). It was therefore proposed to create a regime that would allow New Zealand to adopt autonomous sanctions, the purpose being, inter alia, to "enable New Zealand to join with like-minded countries in sending a signal to foreign governments and responsible individuals and entities that fail to abide by recognised international standards" (ibid.). Another illustration is Canada, whose Minister of Foreign Affairs described sanctions as an essential foreign policy tool that Canada should adopt alongside its allies and like-minded partners in order to defend its values and to play a leadership role in response to international crises (Minister of Foreign Affairs, Canada, 2017). Unlike sanctions adopted by the UN Security Council, Canada's decision to adopt sanctions alongside the EU and the US is entirely discretionary. Charron and Aseltine (2016) have found that Canadian sanctions are impotent in terms of influencing behavioural change. Instead, "they are, at best, a signal of Canada's desire to support collective 
action" adopted by its allies. This group of like-minded states demonstrate their commitment to the norm that was violated, signal the consequences of norm violation and assert their disapproval of the target's behaviour. They also position themselves as taking the lead in situations that pose a threat to the international values they believe should be respected. In signalling their commitment to international norms, sanctioners distinguish 'normal' behaviour from 'deviant' or 'abnormal' behaviour. Through stigmatization they reinforce concepts of normality, as understanding what is 'right' requires understanding what is 'wrong' (Adler-Nissen, 2014; Smetana, 2019). In sum, if sanctions would fail to coerce a change in behaviour, their use would still be justified through their signalling effect that affirms the importance of the violated norm (Jones and Portela, 2020). However seeing as these policy tools also include the imposition of costs they are much more than a form of stigmatization, they constitute international punishment.

Punishment has been defined as the imposition of a "concrete cost (the deprivation of something of value) [and] a public expression of the community's moral disapproval of the act" (Nossal, 1989: 306). Nossal contends that if "sanctions are policy responses to acts perceived by the sender to be acts of moral wrongdoing, it is difficult to exclude the punitive objective of sanctions" (ibid.: 308). Sanctioners are motivated to adopt sanctions by the desire, or intention, to punish wrongfulness. Even if the sender has another purpose in mind when adopting the measures, as long as they consist of the imposition of costs and remain interlinked to norms, their punitive effect on the target is always guaranteed. According to Nossal, punishment does not require that there is a general agreement on the value of the violated norm. The present author agrees that sanctions are necessarily punitive, regardless of whether they are adopted within the context of a shared international order, where all actors have the same understanding of normative expectations (for an alternative view see Lang, 2008: 81-82). It should be noted that in other disciplines, such as psychology, punishment does not always follow normative violations (Dubreuil, 2010: 36). It can be imposed in response to any behaviour that is considered 'wrongful' or 'undesirable'. That being said, when justifying sanctions, senders frequently invoke the normative violation committed by the target. This is demonstrative of the sanctioner's belief (or at least that it wants its audience to believe) that it is enforcing a widely accepted norm, or that it is promoting a norm that should be widely accepted. This points to punishment's expressive function. The expressive theory of punishment finds these actions to be justifiable because they enable society to express its condemnation for criminal offenses (Glasgow, 2015). 
Punishment does not only signal, like stigmatization, what the norms of the international community would be, but it would presumably give expression to the emotional response that is triggered by normative violations. Moral emotions have been defined as those "evoked by violation of or threat to some personally valued moral standard, principle, or ideal” (Batson, 2011: 233). The most frequent emotion that is discussed in the literature as a trigger to punishment is anger (Dubreuil, 2015). Anger exists in many variations, and, according to Dubreuil (2010 and 2011), punishment can by triggered by righteous anger and indignation, though 'cooler' forms or anger such as contempt or disgust can also give rise to sanctioning. Emotions are gaining traction in international relations as scholars are gradually taking stock of their influence on state behaviour. It does not seem far-fetched to argue that decision-makers are

Punishment does not only signal, like stigmatization, what the norms of the international community would be, but it would presumably give expression to the emotional response that is triggered by normative violations. emotionally triggered by wrongdoing, which can motivate their desire to impose sanctions. For instance, though Hellquist takes note of the EU's institutionalised approach to sanctions - sanctioning "is what the EU does" in response to normative violations (Hellquist, 2019: 400) -, she observes that they are justified in emotional language. The Council "routinely" notes: "it is 'appalled and deeply dismayed', 'disappointed', 'extremely worried', or 'alarmed" by the target's behavior (ibid, references omitted). How a state defines itself can also motivate punishment. For instance, if the EU and the US define themselves as 'normative powers' (Manners, 2003; Diez, 2005) or as actors that care about international norms (Hellquist, 2019), then sanctions are a tool through which they can activate this identity and play a role on the international stage (McCourt, 2012).

Dubreuil notes how: "Moral transgressions can [...] trigger significantly different reactions depending on the identity of the observer, her sensitivity and background assumptions" (Dubreuil, 2015: 477, drawing from Calvien et al., 2012). It is not only a matter of what normative violations would trigger sanctions, but also who may be sanctioned. It is known that not all wrongful acts trigger the same response; especially in international relations, states are inconsistent in sanctioning deviant behaviour. The EU refrains from ostracising its own member states presumably because such policies would increase tensions and potentially cause the division of the European community, a risk EU leaders are unwilling to take (Hellquist, 2019). Similar considerations apply to the international community. According to Erickson (2020), even in 
the face of severe violations "valuable relationships" generally discourage states from imposing sanctions. She suggests strategic sanctioning "may indicate that protecting relationships and associated interests is part of the metanorm" (ibid.: 117). What is of interest here is the role that punishment allows the sanctioner to adopt. It has been suggested that moral principles may serve "to evaluate and control others' behavior" (Batson, 2011: 234). Those that seek to uphold the status quo would speak in terms of moral propriety, invoking standards that "address the natural and social order - the way things should be" (ibid.: 233). This points to the manner in which punishment enables states to claim a position of authority, whereby it would be endowed to sanction normative transgressions on behalf of the international community.

In spite of the theoretical sovereign equality between states, foreign policies are driven by states' pursuit of status and recognition in international relations (Badie, 2014; Zarakol, 2011). A means through which actors can assert their status is through the imposition of punishment. In implementing sanctions, states not only affirm their identity as actors "that [care] for the preservation of international norms" (Hellquist, 2019: 405), they also (attempt to) affirm their status within the international order. Punishment is therefore an authority-affirming tool in inter-state relations. Such practices suggest, or create, a hierarchy between the sanctioner and the sanctioned. Hierarchy can be "understood broadly as any system through which actors are organised into vertical relations of super- and subordination"; practices that create hierarchies "stratify, rank and organise" the relations between actors in the international system (Bially Mattern and Zarakol, 2016: 625; see also Zarakol, 2017). Sanctions adopted in response to wrongdoing rank states as 'good' or 'bad' actors based on their compliance with norms, at least according to the sender's system of values. In his study on unequal sovereigns, Simpson (2003) argues that one of the sources of inequality is the moral positioning of states, including the elite's labelling of other states as "outlaws". The "elite" is a group of states that comprises the "Great Powers" and "a large mass of middle and smaller powers who differ to them". In his words: "The Great Powers often identify or define the norms that place certain states in a separate normative universe and there is an identifiable connection between the propensity of the Great Powers to intervene on behalf of the international community and the labelling as outlaws some of those states subject to intervention". Being a "Great Power" is to have a "right to intervene in the affairs of other states in order to promote some proclaimed community goal" (ibid.: 5). States, however, do not have an unlimited right to intervene in the affairs of others. In particular, the use of force is prohib- 
ited under international law. The prohibition would, amongst others, assert "the importance of state equality by mitigating the effects of superior military force and placing states on a level footing in relation to the unilateral use of force" (Simpson, 2003: 29). However, under current international law, there is no prohibition against the use of economic sanctions, which remain a measure of self-help through which states can assert their rights or community interests. The ability of states to have recourse to measures of self-help is unequally distributed. To quote another writer: "an uneven distribution of power to impose unilateral targeted sanctions is cementing de facto inequality between states" (van Aaken, 2019: 130). Consequently, through the imposition of punishment, sanctioners are able to take advantage of their economic and political power to impose harm.

To the extent that the EU and the US are powerful trading partners, being cut-off from their market can have drastic implications. Through the weaponization of its currency, whereby an actor is prevented from trading in dollars thereby cutting them off from the dollar-based financial system, the US possesses unrivalled sanctioning power (Zoffer, 2019). This type of sanction is extraterritorial; it extends beyond persons under US jurisdictions and is enforced against third parties. The EU has frequently condemned US extraterritorial sanctions since the adoption of the Cuban Liberty and Democratic Solidarity (Libertad) Act of 1996 (Helms-Burton Act). Their current application against Iran has created friction between the US and the $\mathrm{EU}$, as EU-based companies are deterred from engaging in business activities in Iran lest they receive hefty penalties for violating US sanctions. In response to the revival of US extraterritorial sanctions, Commissioner for Justice, Consumers and Gender Equality Věra Jourová, spoke on behalf of then High Representative of the Union for Foreign Affairs and Security Policy Federica Mogherini and affirmed: "We Europeans cannot accept that a foreign power - not even our closest friend and ally - takes decisions over our legitimate trade with another country" (Jourová, 2018). As discussed above, the EU is not alone in contesting the diktat of a foreign power. In spite of the fact that there is no prohibition to adopt unilateral sanctions, states repeatedly contest these measures' legality and legitimacy. This is explained by the fact that other actors of the international community - in essence those that are labelled as deviants and that align with them - may feel resentment against those that posture themselves as authorities and may therefore contest hierarchy creating practices. 


\section{Managing resentment against punishment through contestation}

As defined above, punishment is the imposition of costs and of stigma in response to behaviour that is (perceived as) wrongful. It is also a hierarchy creating practice, where the actor imposing the punishment adopts the role of an authority and places the deviant in the role of a subordinate. From a normative standpoint, it is assumed that the mere adoption of punishment is sufficient to strengthen the norm. However, very little consideration has been given to how sanctions achieve their normative objectives. As Hellquist (2019) writes, if the EU justifies its restrictive measures as "necessary, inevitable" responses to severe norm violations, it leaves "the target's expected reaction unspecified". This article argues that when states react to punishment, they respond not only to the imposition of stigma but also to the inferior role that they are placed in. This section begins with a brief overview of stigma management and how it relates to contestation. It then proceeds with a discussion on how resentment against being placed in a lower position can explain contestation against sanctions and the re-affirmation of principles that safeguard sovereign equality.

In her seminal article, Adler-Nissen (2014) provides a typology of three stigma management strategies. A stigmatized actor may recognize the stigma, in which case it accepts the same norms as the stigmatizer and will make efforts to comply with international norms. A deviant may reject the stigma; here it accepts the stigmatizer's normative categories but denies being different. Finally, the wrongdoer may opt for counter-stigmatization whereby it turns the stigma into an emblem of pride while the one imposing the stigma is framed as the transgressor. Based on this typology, states manage their stigma by negotiating their position in the international community (see also Zarakol, 2011). Stigma management can either strengthen the normative order (in the case of stigma recognition and rejection) or divide it (counter-stigmatization). Adler-Nissen's understanding of the normative consequences of stigma management and how states manage stigma through contestation has been further refined and elaborated. Chwieroth (2015) demonstrates these strategies have transformative potential. States that reject or counter-stigma have the possibility to re-shape and re-interpret the international order so that it more accurately mirrors their normative preferences. Therefore "deviant states can become 'norm entrepreneurs' or 'change agents' in seeking to ease or eliminate the stigma through argument and persuasion" (ibid.: 49). The success of these strategies depends on the extent to which the language ad- 
opted by the deviant resonates with the normative beliefs of the normal states. This is less likely in the context of counter-stigmatization, as the stigmatized state does not share the same normative basis as those passing as normal. In Chwieworth's analysis, norms are once again used to improve a stigmatized state's position. Another illustration is Smetana (2019), who provides a sophisticated analysis of stigma politics, which he explains as a process through which deviance is negotiated between the deviant and its audiences. These processes clarify the boundaries between accepted and rejected behaviour in international society, and therefore touch upon normative change and stability in the international order (ibid.: 15; see also Smetana and Onderco, 2018). Smetana also suggests that "the dynamics of deviant (re)construction should be considered against the backdrop of broader norm contestation processes in international politics" (ibid.: 59-60). Within these interactions, "intersubjective meanings, legitimacy, and hierarchy of international norms are continuously re-established" (ibid.). The hierarchy of norms is a question of the weight and position of norms within the normative order; disagreements can occur over norms' precedence. A strategy that deviant actors may employ is ordering discourse, ${ }^{1}$ through which "actors contest not the meaning or the validity of the norm, but its inferiority vis-à-vis a superior normative standard" (Smetana and Onderco, 2018: 526). This already points to what was discussed above; states that contest sanctions do not necessarily dispute the validity of the norm that the sanctioners are seeking to enforce, but re-assert the primacy of multilateralism and its corresponding values over unilateralism.

This brief overview illustrates how norms and their interpretation are instrumental to how stigmatized states negotiate their position in international society. This is hardly surprising, after all, norms are a means through which states are stratified and ranked. As this contribution further suggests, states that have been punished and that would want to contest the inferior rank they have been placed in may resort to contesting the adoption of sanctions, either by contesting the legality of the sanctions themselves in reference to metanorms and/or by disputing the existence of a violation. These practices would therefore be a combination of counter-stigmatization - objecting to the legality of the sanctions and placing the sanctioner in the position of the

1. This is just one of the three strategies Smetana and Onderco (2018) raise in their study, other strategies include applicatory contestation and affirmation and justificatory contestation and affirmation. See also Smetana (2019, chapter 3). 
deviant - or stigma rejection - accepting the validity of the norm that the sanctioner seeks to enforce but denying the norm has been violated. They can also involve ordering discourses, as the target and those that align with it will re-assert that priority should be given to multilateral values. These forms of contestation would arise from the punished actor's resentment against being placed in a lesser social position.

If emotions, such as shock, anger, disgust, or contempt, trigger the impulse to punish wrongful behaviour, then it would not be unusual that being punished would trigger emotions within the target. Although social-psychological factors and emotions are largely absent from the studies on norm diffusion (Smetana, 2019: 67-68), part of how normative enforcement is expected to work relies on these dynamics. Compliance often rests upon an actor sharing the group's normative values and wanting to be a part of that group. For instance, it is anticipated that actors that belong to a given social group will want to comply with that group's expectations so as to avoid being an outcast. If an actor would not comply, it is further expected that, for example, 'naming and shaming' practices will engender shame and thereby motivate it into changing its behaviour. Shame causes an actor to feel unworthy and is usually generated when someone believes they have not acted competently or that they have failed to behave in a manner that meets social expectations (Turner, 2007). However, how this emotion influences behaviour may be more complex than assumed. An actor may feel shame, as anticipated, but this can lead to intense negative emotions. According to Turner (2016), within society negative sanctions - which, like those that are imposed in international relations, constitute the withdrawal of a benefit or the imposition of costs - arouse negative emotions. These "activate defense mechanisms and the external bias driven by attribution dynamics. Thus, societies in which there is a considerable amount of punishment generating anger and shame will generally produce large pools of negative emotional arousal among subpopulations and, as a consequence, make a society less stable. (...) Even when people have come to expect this fate, the sanctions themselves arouse negative emotions that, if sufficiently widespread and intense, can cause conflict and change in a society" (ibid.: 142).

It follows that sanctions adopted to strengthen legal norms, if not through their enforcement then through signalling the norm's importance, can have consequences that interfere with this goal if it arouses negative emotions within the target. In the context of the international order, where no central authority exists, the imposition of punishment can stir resentment within the punished actor. To be clear, the focus on resentment does not exclude the possibility 
that other emotions may come into play in the context of punishment. For instance, in the excerpt quoted above Turner raises anger and shame, whereas Badie (2014) focuses on humiliation. Due to the limited scope of this discussion, resentment, or 'ressentiment', has been chosen because it more aptly captures inter-state interaction in the horizontal context within which states battle for status and recognition. Described as a reaction to treatment that is perceived as unjust or unfair, resentment is an emotional response that relates to one's social status (Brighi, 2016). Wolf (2018) writes that ressentiment is the feeling that one's social status is 'undeserved', particularly in comparison to others who enjoy a higher social status according to established norms and values. It is a grievance that leads to frustration and a desire to correct the perceived unjust situation. A resentful actor is more likely to ascribe illegiti-

The sanctions adopted to strengthen legal norms can have consequences that interfere with this goal if it arouses negative emotions within the target. In the context of the international order, where no central authority exists, the imposition of punishment can stir resentment within the punished actor. mate motives to the actor deemed responsible for creating the unfair situation. This links to Turner's theory on negative emotions and change: segments of the population where there is negative emotional arousal will be motivated to change or challenge the status quo.

One of the keys to resentment is that the resentful actor is usually in a less powerful position and consequently unable to respond. Contrary to "hot emotions" such as anger, the resentful subject will not act upon this negative feeling right away but will wait for the opportune moment to correct the perceived wrong (Wolf, 2018). Resentment may be smouldering beneath the surface until the opportunity arises to take action and adjust the status quo. In the meantime, the entity feeling resentment will protest against its 'lesser' status and may seek allies "who might later support forceful attempts to cut down the object of resentment" (ibid.: 236). He writes: "Resentful persons or groups see themselves confronted with an "unfair" but stable status hierarchy and therefore perceive a special need for allies or other kinds of supporters. In order to mobilize their support, they must try to convince these parties - be they bystanders or reluctant in-group members - of the legitimacy of their cause. They need to explain their grievances and must justify the means by which they seek to redress the "unfair" status" (ibid.: 237). It is noteworthy that Chwieroth's description of counter-stigmatization echoes the behaviour adopted by a resentful actor as described by Wolf: "Counter-stigmatizers emerge because they have strong notions about legitimate behaviour, which clash with the norms embraced by 
the normal states. These actors may seek alliances with other deviants or, especially when they have sufficient material and social resources, they may pursue efforts to transform the international normative order so it is more consistent with their norms. Such alliances and resources, as well as a lack of normative agreement among the normal states, may provide a window of opportunity for the deviant states to improve their position" (Chwieroth, 2015: 49-50; emphasis added).

Actors imposing punishment adopt a position of authority and stigmatize the punished actor for its bad behaviour, thus placing it in a lower rank. However, the punished state may not accept the role it is placed in; in fact, it may resent it. In an effort to correct its undeserved social status, it would seek to adjust the status quo and challenge the sanctioners, ideally through an alliance. This may therefore cause the deviant to resort to strategies of stigma rejection or counter-stigmatization, which would involve contesting the legality of the sanctions and/or their appropriateness. It could dispute the validity of the norm that would have been violated, the interpretation of the norm by the sanctioners, or the legality of the sanctions themselves. In the third instance, the disagreement revolves around the metanorms that determine when and how norms can be enforced. The dispute is not centred on the norm that the sanctioners are seeking to enforce but the practices that are adopted to enforce them. In this case, states may agree on the norms that lie at the basis of the international order but contest how they are enforced. They would invoke the organising principles, or the metanorms, that should structure inter-state relations but that the sanctioner would have violated.

\section{Two illustrations: Russia and Venezuela's management of sanctions}

Russia is perhaps the most evident example as it defines itself as a Great Power and is described as a "status seeking" power in IR literature (see, for instance, Zarakol, 2011). In punishing Russia, the West denies its status and refuses to it treat as an equal. Concerned with its status, Russia rejects the role of the deviant and presents itself as an 'untouchable' state that cannot be influenced by foreign powers (discussed further Hofer, 2020). The Kremlin has adapted to the sanctions by adopting a strategy that lies between 'stigma rejection' and 'counter-stigma' and that mirrors the actions of a resentful action as described by Wolf. It rejects the stigma by negating any wrongdoing in Ukraine, either by denying it is providing support to the rebel groups or by 
claiming that the annexation of Crimea was a lawful exercise of the Crimean people's right to self-determination. It therefore does not contest the validity of the prohibition to use force and seems to share the same values as the West, although it understands them differently. That being said, adopting a counterstigmatizer strategy, Russia presents the senders as deviants. The EU and US sanctions are presented as an illegitimate attempt to 'weaken' and 'demonize' Russia, furthering the policy of containment that has been in place since the Cold War. It contests the legality of the unilateral sanctions in claiming they violate international law, namely the UN Charter, WTO rules and bilateral agreements between Russia and the sending states. Though the unilateral coercive measures adopted against Russia would be illegal, its own countersanctions would be legitimate; particularly when they are adopted within the prescribed security exceptions (WTO, Panel Report). The retaliatory countermeasures come across as an attempt to teach the sanctioners a lesson (Wolf, 2018). Russia has consistently claimed it will lift their own measures after the senders lift theirs; thereby suggesting the sanctioners need to suffer the consequences of their own actions.

The Venezuelan regime has been punished by the US since 2015 for grave human rights violations. When the crisis intensified in 2017, so did the US sanctions, and the EU and Canada followed suit in implementing sanctions of their own. Venezuela has challenged the legality of the US sanctions before the World Trade Organization and has gone as far as accusing the US of committing crimes against humanity in referring the sanctions to the International Criminal Court (ICC, Venezuela Referral). Venezuelan leaders seem to have adopted the 'counter-stigma' strategy. As just argued, they seek to transform the normals into deviants. They furthermore appear to bear the stigma as an emblem of pride. Through their speech acts, they express their resentment by invoking "emotionally loaded terms for describing the status asymmetry" and "[e]xpressions of moral indignation or disgust toward alter's character" (Wolf, 2018). According to Maduro, the Venezuelan people have been subjected to "the most evil and embarrassing attacks in the last years; for [Venezuela] is a harassed and attacked country" (President Maduro, 2018). Denying any wrongful conduct, the unilateral coercive measures are framed as an imperial policy imposed by the US that aspires to cause regime change in violation of international law (Venezuela, General Debate, 2017) but that Venezuela proudly withstands. Foreign Minister Arreaza reportedly claimed to be "proud" that Venezuela and Cuba were listed as US adversaries, stating "If Trump had applauded us, we would be on the road to damnation" (Telesur, 2018). Human rights violations would be used as a pretext to punish 
Venezuela for its socialist economy and interfere in its internal affairs. Resentful actors express satisfaction at minor setbacks experienced by alter (Wolf, 2018). Clearly, Maduro expressed victory when the US-backed 'coup' by Juan Guiado, the President of the National Assembly, failed miserably in 2019 (The Guardian, 2019). Though Maduro's regime has been able to gather some international support, it is increasingly isolated, including by regional actors. Nonetheless, if Venezuela continues to maintain pride in being sanctioned and to resent the sanctioners 'imperialist' policies, it is likely to resist the measures for as long as possible.

Recall how counter-stigmatizers and resentful actors would seek alliances with other actors for support in an attempt to transform the normative international order. Russia has issued statements alongside China, India, and BRICS declaring that unilateral coercive measures are contrary to international law. In November 2017, Russia, China and non-permanent members boycotted an informal UN Security Council meeting on the Venezuelan crisis that was called by the US. These states claimed that the issue was a domestic matter in which external actors should not meddle (Reuters, 2017). Sanctioned states like Russia and Venezuela have been able to align with groups such as the G77 and NAM. Resentment is expressed through the re-affirmation of the importance of multilateralism, the peaceful settlement of disputes, the principle of non-intervention and, logically, sovereign equality. These groups' state practice contributes to challenging the legality of unilateral coercive measures, but they have not yet succeeded in transforming the status quo (Hofer, 2017a). While sending states refer to themselves as 'likeminded' and call for cooperation in adopting sanctions, resisting states call for support and solidarity against unilateral measures.

\section{Conclusion}

The added value of analysing sanctions as a form of punishment is that it not only provides a more accurate picture of what states do when they impose sanctions (as well as why they continue to adopt them, Nossal, 1989) but it also provides further opportunities to appreciate how states respond to these tools. In defining sanctions as punitive, they are explained as a role affirming and hierarchy creating practice in a system that lacks a central authority. The rub lies in the fact that other members of the international community, such as those that do not differ to the so-called Great or nor- 
mative Powers, do not accept this role. It is because punitive acts create, or at the very least attempt to create, inter-state hierarchy that they trigger reactions, notably resentment, within targeted states that can influence how they manage punishment, which can lead to contesting the legality and legitimacy of unilateral sanctions. In contesting sanctions, targets may rely upon a pool of allies that also have grievances against these unilateral tools. It has been argued that through contestation, states express their resentment against the position of authority adopted by the sanctioner. Contestation against unilateral coercive measures therefore entails invoking the norms that would place the senders and the targets on more equal footing. In objecting unilateral sanctions, states invoke their preference for behaviour that respects multilateralism, notably the peaceful settlement of disputes and non-interventionist practices.

Contestation against unilateral coercive measures therefore entails invoking the norms that would place the senders and the targets on more equal footing. In objecting unilateral sanctions, states invoke their preference for behaviour that respects multilateralism.

essentially a disagreement over how norms should be enforced in the international system.

Senders are not ignorant of the fact that sanctions increase inter-state tensions. As mentioned above, states revealingly refrain from jeopardizing valuable relationships and adopt sanctions strategically. Erickson finds that the selective imposition of sanctions demonstrates states' awareness that these tools can give rise to tensions and "highlight[s] the potential value of other tools of enforcement and socialization" (Erickson, 2020: 117). She also suggests that protecting valuable relationships is part of the metanorm (ibid.). To the extent that these metanorms would involve not treating other actors as inferior and to solve disputes through non-coercive measures, they would not only be shared by the targets of sanctions and their supporters, but also by the most active sanctioners. It is perhaps on this basis that developed and developing states can find common ground and agree on appropriate enforcement practices in the horizontal global order. After all, it is nothing short of a paradox that a horizontal system depends upon vertical measures for enforcement. 


\section{Bibliographical references}

Adler-Nissen, Rebecca. "Stigma Management in International Relations: Transgressive Identities, Norms, and Order in International Society". International Organization vol. 68, issue 1 (2014), p. 143-176.

Badie, Bertrand, Le Temps des Humiliés: Pathologie des Relations Internationales. Paris: Odile Jacob, 2014.

Batson, Daniel C., "What's wrong with morality?" Emotion Review, vol. 3, issue 3 (2011), p. 230-235.

Bially Mattern, Janice, and Ayse Zarakol, "Hierarchies in World Politics" International Organization, vol. 70, (2016), pp. 623-656.

Brighi, Elisabetta. "The Globalisation of Resentment: Failure, Denial, and Violence in World Politics". Millenium, vol. 44, issue 3 (2016), pp. 411-432.

Charron, Andrea and Paul Alestine. "Calling a Spade a Spade: Canada's Use of Sanctions". Canadian Global Affairs Institute, Policy Paper, (December 2016) https://www.cgai.ca/calling_a_spade_a_spade_canadas_use_of_ sanctions\#Top

Chwieroth, Jeffrey M. "Managing and transforming policy stigmas in international finance: Emerging markets and controlling capital inflows after the crisis". International Political Economy, vol. 22, issue 1 (2015), pp. 44-76.

Deitelhoff, Nicole y Zimmermann, Lisbeth. «Norms under Challenge: Unpacking the Dynamics of Norm Robustness». Journal of Global Security Studies, vol. 4, issue 1, (2019), p. 2-17.

Diez, Thomas. "Constructing the Self and Changing Others: Reconsidering "Normative Power Europe"”. Millennium Journal of International Studies, vol. 33, issue 3 (2005), pp. 613-636.

Dubreuil, Benoît. "Punitive emotions and norm violations". Philosophical Explorations vol. 13, issue 1 (2010), pp. 35-50.

Dubreuil, Benoit. Human Evolution and the Origins of Hierarchies: The State of Nature. Cambridge: Cambridge University Press, 2011.

Dubreuil, Benoît. "Anger and Morality". Topoi, vol. 34, issue 1 (2015), pp. 475-482.

Erickson, Jennifer L. "Punishing the violators? Arms embargoes and economic sanctions as tools of norm enforcement". Review of International Studies, vol. 46, issue 1 (2020), pp. 96-120.

Glasgow, Joshua. "The Expressivist Theory of Punishment Defended". Law and Philosophy, vol. 34, (2015), pp. 601-631.

Hellquist, Elin. "Regional Organizations and Sanctions Against Members: Explaining the Different Trajectories of the African Union, the League of 
Arab States, and the Association of'Southeast Asian Nations" KFG Working Paper Series, issue 59 (January 2014) (online) https://core.ac.uk/download/ pdf/199427851.pdf.

Hellquist, Elin. "Interpreting Sanctions in Africa and Southeast Asia". International Relations, vol. 29, issue 3 (2015), pp. 319-333.

Hellquist, Elin "Ostracism and the EU's contradictory approach to sanctions at home and abroad". Contemporary Politics, vol. 25, issue 4 (2019), pp. 393-418

Hofer, Alexandra. "The Developed/ Developing Divide on Unilateral Coercive Measures: Legitimate Enforcement or Illegitimate Intervention?" Chinese Journal of International Law, vol. 16, issue 2 (2017a), p. 175-214.

Hofer, Alexandra. "Negotiating International Public Policy through the Adoption and Contestation of Sanctions". Revue Belge de Droit International, (2017b), p. 440-473.

Hofer, Alexandra. "All the World's a Stage, and Sanctions the Merely Props: an Interactional Account of Sender-Target Dynamics in the Ukrainian Crisis". International Peacekeeping, (2020) available online https://doi.org/10.1080 /13533312.2020.1753513.

Jones, Lee and Clara Portela. "Evaluating the Success of International Sanctions: A New Research Agenda". Revista CIDOB d'Afers Internacionals, issue 125 (September 2020).

Jourová, V ra, "Speech on the extraterritorial effects of US sanctions on Iran for European companies, at the European Parliament". EEAS Press Team, (14 November 2018) (online) [Accessed 3/01/2020] https://eeas.europa. $\mathrm{eu} /$ headquarters/headquarters-homepage/ $53860 /$ speech-extraterritorialeffects-us-sanctions-iran-european-companies-european-parliament_en

Lang, Jr, Anthony F. Punishment, Justice and International Relations: Ethics and Order after the Cold War. London: Routledge, 2008.

Maduro, Nicolas. "Statement by the President of the Bolivarian Republic of Venezuela Nicolas Maduro during the 73rd Session of the United Nations General Assembly". United Nations, (26 September 2018) (online) https:// gadebate.un.org/sites/default/files/gastatements/73/ve_en.pdf

Maduro, Nicolás. "Venezuela Referral". International Criminal Court, (12 February 2020) (online) https://www.icc-cpi.int/itemsDocuments/200212venezuela-referral.pdf

Manners, Ian. "Normative Power Europe: A Contradiction in Terms?". JCMS, vol. 60, issue 2 (2002), pp. 235-58.

McCourt, David M. "The roles states play: a Meadian interactionist approach". Journal of International Relations and Development, vol. 15, (2012), pp. 370-392. 
Minister of Foreign Affairs, Canada. "Government Response to the Seventh Report of the Standing Committee on Foreign Affairs and International Development", House of Commons of Canada, (17 July 2017) [Accessed 1/01/2020] http://www.ourcommons.ca/DocumentViewer/en/42-1/ FAAE/report-7/response-8512-421-189.

Nichols, Michelle. "Russia, China, others boycott U.S. meeting at U.N. on Venezuela”. Reuters, (13 November 2017) (online) www.reuters.com/article/us-venezuela-politics-un/russia-china-others-boycott-u-s-meeting-atu-n-on-venezuela-idUSKBN1DE056

Nossal, Kim Richard. "International Sanctions as International Punishment". International Organization, vol. 43, issue 2 (1989), p. 301-322.

OHCHR-Office of the United Nations High Commissioner for Human Rights. Human rights violations and abuses in the context of protests in the Bolivarian Republic of Venezuela from 1 April to 31 July 2017. United Nations, (August 2017) (online) www.ohchr.org/Documents/Countries/VE/ HCReportVenezuela_1April-31July2017_EN.pdf

Philips, Tom. "Venezuela crisis: Maduro claims victory over 'deranged' coup attempt". The Guardian (1 May 2019) (online) https://www.theguardian. $\mathrm{com} /$ world $/ 2019 / \mathrm{may} / 01 /$ venezuela-crisis-maduro-claims-victory-overderanged-us-backed-coup-attempt

Simpson, Gerry. Great Powers and Outlaw States Unequal Sovereigns in the International Legal Order. Cambridge: Cambridge University Press, 2003.

Smetana, Michal. Nuclear Deviance: Stigma Politics and the Rules of the Nonproliferation Game. London: Palgrave MacMillan, 2019.

Smetana, Michal y Onderco, Michal. "Bringing the outsiders in: an interactionist perspective on deviance and normative change in international politics". Cambridge Review of International Affairs, vol. 31, issue 6 (2018), p. 516-536.

Telesur. "Venezuelan Foreign Minister Arreaza "Proud" to be United States' Adversary". Telesur, (2 February 2018) (online) https://www.telesurenglish.net/news/Venezuelan-Foreign-Minister-Arreaza-Proud-to-be-UnitedStates-Adversary-20180202-0008.html

The Treasury New Zealand. "Regulatory Impact Statement", (10 May 2017) (online) [Accessed: 27/08/2020] https://treasury.govt.nz/sites/default/ files/2017-01/ris-mfat-asn-may17.pdf.

Turner, Jonathan H. Human Emotions, A Sociology Theory. London: Routledge, 2007.

Turner, Jonathan H. "The Macro and Meso Basis of the Micro Social Order". In: Seth Abrutyn (ed.). Handbook of Contemporary Sociological Theory. New York: Springer, 2016, p. 123-148. 
Van Aaken, Anne. "Introduction to the Symposium on Unilateral Targeted Sanctions". AJIL Unbound, Symposium on Unilateral Targeted Sanctions, vol. 113, (2019), p. 130-134.

Weiner, Antje. "Contested Meanings of Norms: A Research Framework". Comparative European Politics, vol. 5, (2007), p. 1-17.

Weiner, Antje, A Theory of Contestation. New York: Springer, 2014.

Wolf, Reinhard. "Political Emotions as Public Processes: Analyzing Transnational Ressentiments in Discourses". In: Clément, Maéva y Sanger, Eric (ed.). Researching Emotions in International Relations: Methodological Perspectives on the Emotional Turn. London: Palgrave Macmillan, 2018, p. 231254.

WTO-World Trade Organization. Russia - Measures Concerning Traffic in Transit. WTO, W/DS512/R, (5 April 2019) (online) https:/www.wto.org/ english/tratop_e/dispu_e/cases_e/ds512_e.htm

Zarakol, Ayse, After Defeat: How the East learnt to live with the West. Cambridge: Cambridge University Press, 2011.

Zarakol, Ayse. Hierarchies in World Politics. Cambridge: Cambridge University Press, 2017.

Zoffer, Joshua. "The Dollar and the United States' Exorbitant Power to Sanction". AJIL Unbound, Symposium on Unilateral Targeted Sanctions, vol. 113, (2019), p. 152-156. 

